Article

\title{
Efficacy of Spent Lime as a Soil Amendment for Nutrient Retention in Bioretention Green Stormwater Infrastructure
}

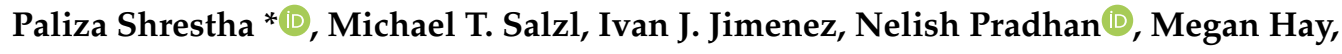 \\ Hannah R. Wallace, Jenna N. Abrahamson and Gaston E. Small \\ Department of Biology, University of Saint Thomas, Saint Paul, MN 55105, USA \\ * Correspondence: shre8493@stthomas.edu
}

Received: 18 June 2019; Accepted: 27 July 2019; Published: 30 July 2019

check for updates

\begin{abstract}
The composition of bioretention soil media (BSM) is among the most critical design attributes contributing to the water quality performance of bioretention systems, as various amendments may increase the capacity for chemical sorption of certain nutrient pollutants. We investigated the spent lime (a calcium-based water treatment residual) as BSM amendments for nutrient retention. The study was conducted in two parts: the first was a field-based mesocosm experiment in which we assessed the effect of spent lime amendments on leachate nutrient concentration for treatments receiving different levels of phosphorus and nitrogen loading (simulated by different levels of compost added to the substrate). The second was a laboratory study comparing various levels of spent lime and coir on leachate nutrient concentration at two different simulated loading rates. Effluent water was collected and analyzed for $\mathrm{PO}_{4}{ }^{3-}, \mathrm{NH}_{4}{ }^{+}$and $\mathrm{NO}_{3}{ }^{-}$concentrations in the field and lab. Spent lime significantly reduced leachate $\mathrm{PO}_{4}{ }^{3-}$ concentrations (upwards of 50\%) in both the field and lab mesocosm studies compared to treatments without spent lime. Reductions in $\mathrm{NH}_{4}{ }^{+}$concentrations were also observed due to spent lime but with variable significance across the different compost levels, whereas $\mathrm{NO}_{3}{ }^{-}$ concentrations were higher in plots with spent lime than plots without spent lime. In the lab, columns with coir had significantly higher leachate $\mathrm{PO}_{4}{ }^{3-}$ concentrations compared to spent lime-treated columns, however, leachate $\mathrm{NH}_{4}{ }^{+}$and $\mathrm{NO}_{3}{ }^{-}$concentrations did not significantly differ between treatments at the same compost levels. This study shows that spent lime, which is a waste product, is effective in significantly reducing leachate $\mathrm{PO}_{4}{ }^{3-}$ concentrations from BSM, while be a cost-effective substitute to engineered proprietary media that is expensive to acquire; however, future studies must also evaluate its potential for clogging.
\end{abstract}

Keywords: bioretention; spent lime; water treatment residuals; coir; compost; phosphorus; nitrogen; water quality

\section{Introduction}

Green stormwater infrastructure (GSI) has become a national stormwater focus and is commonly being implemented in cities as part of their stormwater management strategy [1]. Bioretention, also known as raingardens, is one of the popular forms of GSI that offers promising solutions to control pollutants (of nutrients such as phosphorus $(\mathrm{P})$ and nitrogen $(\mathrm{N})$ that stormwater management community is struggling to address) from urban storm runoff to combat eutrophication and harmful algal blooms (e.g., toxic Cyanobacteria and Microcystis) in the receiving waters. Bioretention comprises porous soil media and vegetation, where runoff is filtered, stored and treated by taking advantage of the different chemical sorption and biological uptake/transformation mechanisms in the soil media [2]. The paradigm has been that these bioretention systems remove $\mathrm{P}$ and $\mathrm{N}$ from stormwater runoff and 
act as nutrient "sinks" on the landscape but existing studies have shown that a significant amount of $\mathrm{P}$ and $\mathrm{N}$ is in fact being leached and exported to the effluent from the soil media used in these systems [3-9] While implementation of bioretention is happening at a rapid pace, not enough attention is paid to the different design attributes of a bioretention, especially, the soil media composition which plays a critical role in the removal capacity of pollutants.

Though many design attributes contribute to an improved performance of bioretention systems, the composition of bioretention soil media (BSM) is among the most critical. The soil media is a critical design element of a bioretention as it is where the infiltration, chemical sorption and biological reactions occur for pollutant removal. Traditional bioretention media utilizes sand to facilitate infiltration, such that there is a trade-off between infiltration and nutrient retention. While a sand-based media offers hydrological benefits, sand is chemically inactive due to its mineral composition and lower surface area [10] and have limited ability to reduce actual pollutant concentrations and subsequently improve water quality. Additionally, removal of some dissolved nutrients like $\mathrm{PO}_{4}{ }^{3-}$ and some forms of $\mathrm{N}$ (e.g., $\mathrm{NH}_{4}{ }^{+}$) is reliant heavily on chemical sorption mechanisms in the soil media [11,12]. Sorption reactions can be maximized by amending the BSM with substrates of high adsorptive properties containing calcium $(\mathrm{Ca})$, iron $(\mathrm{Fe})$ and aluminum $(\mathrm{Al})$ ions where $\mathrm{P}$ can react with these metal ions on substrate surfaces and precipitate as insoluble compounds [13]. Among the various kinds of waste materials that have been identified with adsorptive properties [14-19], water treatment residuals (WTR), rich in $\mathrm{Al}$, $\mathrm{Fe}$ or $\mathrm{Ca}$, have received growing attention for its potential use as a bioretention soil amendment for P sorption [20-24]. However, such studies have focused almost exclusively on WTR that is predominantly Al-based and few have described WTR properties in their study, so less is known about the efficacy of other forms, such as Ca-based WTR (also known as spent lime), in retaining nutrients. Because composition of WTR varies widely across time spans and regions (due to different source water and varying types and doses of treatment chemicals $[25,26]$, it is important to evaluate WTR from each source before field application, as results are expected to vary.

In this study, we conducted field and laboratory trials to investigate the efficacy of spent lime in retaining dissolved $\mathrm{P}$ and $\mathrm{N}$ that may otherwise leach from bioretention media. In the field-based mesocosm experiment, we assessed the effect of spent lime amendments on leachate nutrient concentration for treatments receiving different levels of $\mathrm{P}$ and $\mathrm{N}$ loading (simulated by different levels of compost added to the substrate). The second was a laboratory study comparing various levels of spent lime and coir on nutrient leachate nutrient concentration at two different simulated loading rates. Coir is the fiber derived from the inner shell of the coconut and a waste by-product generated from the coconut industry [27]. We hypothesize that WTR will reduce P concentrations due to its high demonstrated sorption potential $[17,28,29]$ but its removal efficiency in terms of the relative mass of dissolved $P$ removed will decrease at higher P loading rates. Effects of spent lime on dissolved $\mathrm{N}$ retention is unknown; however, the cation exchange properties of WTR [25] may allow removal of $\mathrm{NH}_{4}{ }^{+}$. Therefore, we also evaluated potential benefits for dissolved $\mathrm{N}$ retention. On the other hand, a limited number of studies have shown coir to have variable $\mathrm{N}$ retention capacities [30,31] attributed to immobilization of soluble $\mathrm{N}$ [32] but more studies are needed for validation (for both $\mathrm{N}$ and potentially $\mathrm{P}$ retention), where the study designs and associated results must be transferable to GSI applications. This research aims to identify opportunities for future improvement of GSI by providing better understanding of what kind of soil media additives in these systems might improve nutrient retention performance.

\section{Materials and Methods}

\subsection{Experimental Setup for Field Mesocosm Study}

We used raised-bed plots for field-simulated experimental BSM at the University of Saint Thomas (UST) Stewardship Garden, Saint Paul, Minnesota, USA. The study examined a combination of eight different soil media treatments (Table 1), with 4 replicates per treatment, resulting in a total of 
32 experimental units (raised-bed plots; Figure 1A). Because our objective in this study was to measure the efficacy of spent lime in leachate nutrient reduction over a range of loading rates, rather than to realistically simulate GSI per se, we used different levels of manure-based compost in the mesocosms to create different loading rates of dissolved $\mathrm{P}$ and $\mathrm{N}$, rather than using actual $[4,5,9]$ or synthetic stormwater $[11,33,34]$ as has been used in other studies. We have previously documented high levels of $\mathrm{P}$ and $\mathrm{N}$ leachate from manure-based compost in the context of urban vegetable gardens [35]. While compost is often incorporated in bioretention media [36-39] and some states recommend compost as an organic matter source in BSM [40-42], we note that compost made from animal manure or biosolids is not recommended [43] and sometimes explicitly prohibited for use in bioretention practices [41]. Because in our study design, nutrient loading was generated internally within the mesocosms, we do not assess nutrient retention as the relative difference between external nutrient inputs and outputs, as is commonly done in GSI studies [5,8,9]. Instead, we focus our analysis on the difference in leachate nutrient concentration between treatments that contain spent lime and control treatments that do not. Soil media treatments were randomly assigned to each of the 32 plots. Soil treatments included homogenized mixes of compost and sand at different volumetric ratios: $100 \%$ compost (compost100), 80\% compost: $20 \%$ sand (compost 80 ), $40 \%$ compost: $60 \%$ sand (compost 40 ) and $20 \%$ compost: $80 \%$ sand (compost20) in the top $17.48 \mathrm{~cm}$ (approx. $0.6 \mathrm{ft}$ ) layer (Table 1).

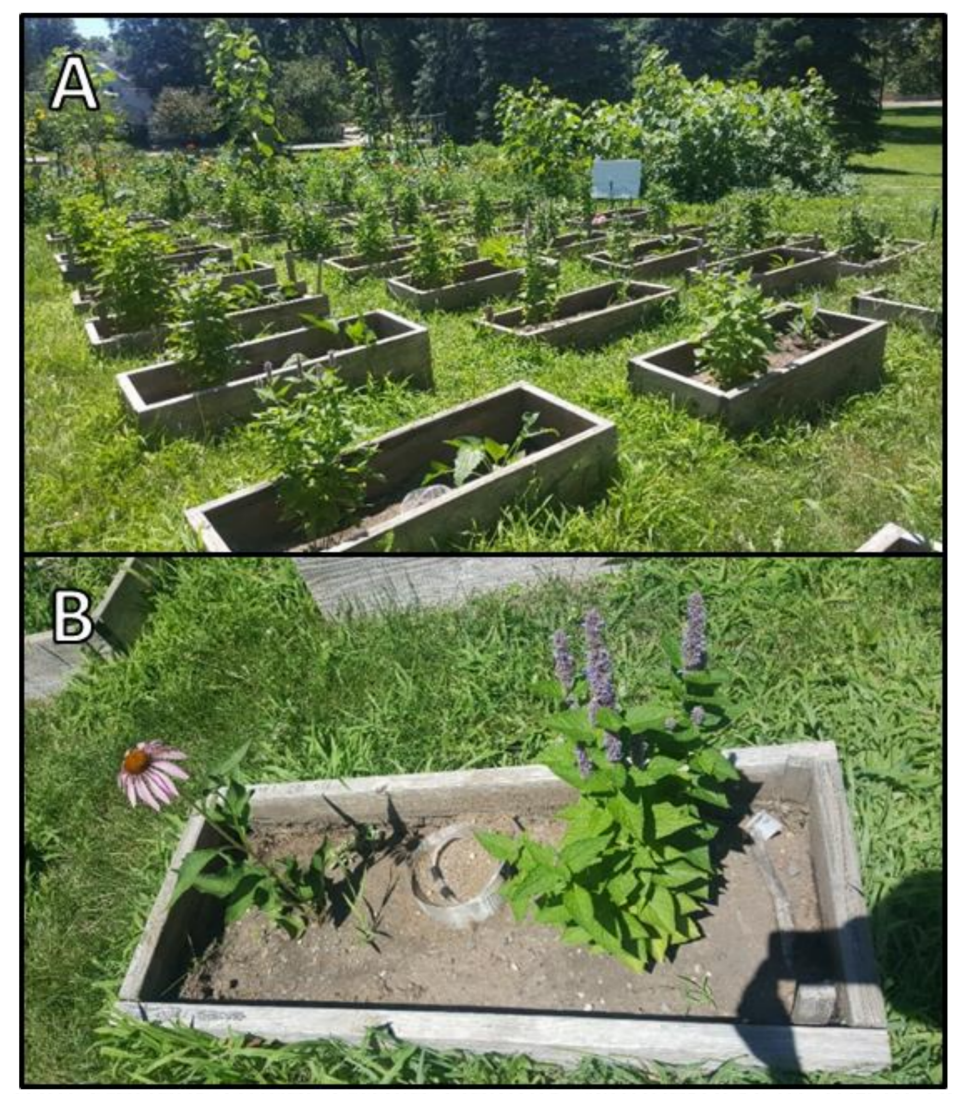

Figure 1. (A) Spatial layout of the plots; (B) Field-based mesocosm with mesh screen and tygon tubing for effluent collection. 
Table 1. Bioretention soil media combinations and depth profile.

\begin{tabular}{ccc}
\hline Media layer depth & Media composition with (+) WTR & Media composition without (-) WTR \\
\hline & $100 \%$ compost & $100 \%$ compost \\
Upper layer: $17.48 \mathrm{~cm}$ & $80 \%$ compost: $20 \%$ sand & $80 \%$ compost: $20 \%$ sand \\
& $40 \%$ compost: $60 \%$ sand & $40 \%$ compost: $60 \%$ sand \\
& $20 \%$ compost: $80 \%$ sand & $20 \%$ compost: $80 \%$ sand \\
\hline Bottom layer: $13 \mathrm{~cm}$ & $60 \%$ WTR: $40 \%$ sand & $100 \%$ sand \\
\hline Total of $30.48 \mathrm{~cm}(1 \mathrm{ft})$ & & \\
\hline
\end{tabular}

Before we filled the raised-bed plots with the different soil media treatments, all the pre-existing soil from the top $45 \mathrm{~cm}$ of the plots were excavated. Half of the plots received spent lime treatment in the bottom $13 \mathrm{~cm}$ layer (design method like Shrestha et al., 2018 [9] where a layer of P adsorbing "SorbtiveMedia ${ }^{\mathrm{TM}}$ " comprised of fine $\mathrm{Al}$ and Fe oxide granules is placed under a sand-based bioretention soil media), while the other half received sand as control. WTR was placed underneath the compost or compost: sand mix layer (and above a pea gravel layer) to capture and retain nutrients from the effluent leachate moving vertically down the soil profile. Where WTR layer was present, a set WTR: sand mix at 60:40 volumetric ratio was utilized (Table 1). Sand was mixed with WTR to ensure that adequate infiltration rates would be maintained. Manure-based compost (chemical properties in Table 2) was purchased from Kern Landscaping in Saint Paul, MN along with the sand. Spent lime was collected from Saint Paul Regional Water Services; this plant generates residuals from a lime-softening process so WTR is predominantly Ca-based (Table 3; refer to Section 2.4 for methods). The spent lime was air dried in the sun and mechanically pounded and crushed into powder form (maximum grain size $\leq$ $5 \mathrm{~mm}$ ) before application.

Table 2. Properties of manure compost and coir.

\begin{tabular}{lcc}
\hline Parameters & Compost & Coir \\
\hline Total P, \% & 0.713 & 0.036 \\
Total K, \% & 1.304 & 0.819 \\
Total organic carbon, \% & 36.88 & 41.831 \\
Total N, \% & 3.24 & 0.5 \\
C:N ratio & 11.40 & 83.66 \\
\hline
\end{tabular}

Table 3. Chemical properties of spent lime.

\begin{tabular}{lr}
\hline Parameters & Value \\
\hline $\mathrm{Ca}, \%$ & 42.4 \\
$\mathrm{Mg}, \%$ & 4.63 \\
$\mathrm{Fe}, \%$ & 1.04 \\
$\mathrm{Al}, \%$ & 0.579 \\
$\mathrm{Na}, \mathrm{ppm}$ & 335 \\
$\mathrm{Mn}, \mathrm{ppm}$ & 159 \\
$\mathrm{P}, \mathrm{ppm}$ & 105 \\
$\mathrm{Cu}, \mathrm{ppm}$ & 12.4 \\
$\mathrm{~Pb}, \mathrm{ppm}$ & 3.59 \\
$\mathrm{Ni}, \mathrm{ppm}$ & 3.42 \\
$\mathrm{Zn}, \mathrm{ppm}$ & $<0.015$ \\
$\mathrm{Cd}, \mathrm{ppm}$ & $<0.001$ \\
$\mathrm{NO}, \mathrm{N}, \mathrm{ppm}$ & $\mathrm{ND}$ \\
$\mathrm{Ammonia}, \mathrm{ppm}$ & $\mathrm{ND}$ \\
$\mathrm{TKN}, \mathrm{ppm}$ & $\mathrm{ND}$ \\
\hline
\end{tabular}


Experimental plots were established by May 25, 2018 (Figure 1A,B). Plots were constructed of cedar wood and were rectangular with aboveground dimensions $0.4 \mathrm{~m}$ wide $\times 1 \mathrm{~m}$ long $\times 0.3 \mathrm{~m}$ deep. Lysimeters were installed in the center of each plots in holes that were $0.3 \mathrm{~m}$ deep from the base (bottom layer) of the plots (Figure 2). Lysimeters were custom-designed [35] and composed of a 23-cm diameter plastic funnel $(0.47 \mathrm{~L})$, secured to a $1 \mathrm{~L}$ wide-mouth plastic Nalgene bottle (Figure 2). Tygon tubing (inside diameter of $0.3 \mathrm{~cm}$ ) extended from the base of the Nalgene bottle through the funnel, to $15 \mathrm{~cm}$ above the soil media surface for effluent water sampling from the surface directly above it. Rock wool was placed in the funnel around the tubing to avoid entry of any solid particles into the bottle and to ensure that the tubing is secured in place. The funnel headspace was filled with pea gravel (approx. $1 \mathrm{~cm}$ diameter) to maintain adequate infiltration of the percolated water from the soil layers to the bottle, while preventing further movement of soil particles into the bottle and contaminating water samples. Lysimeters were buried so that the top of the funnel was level with the base of the plots.

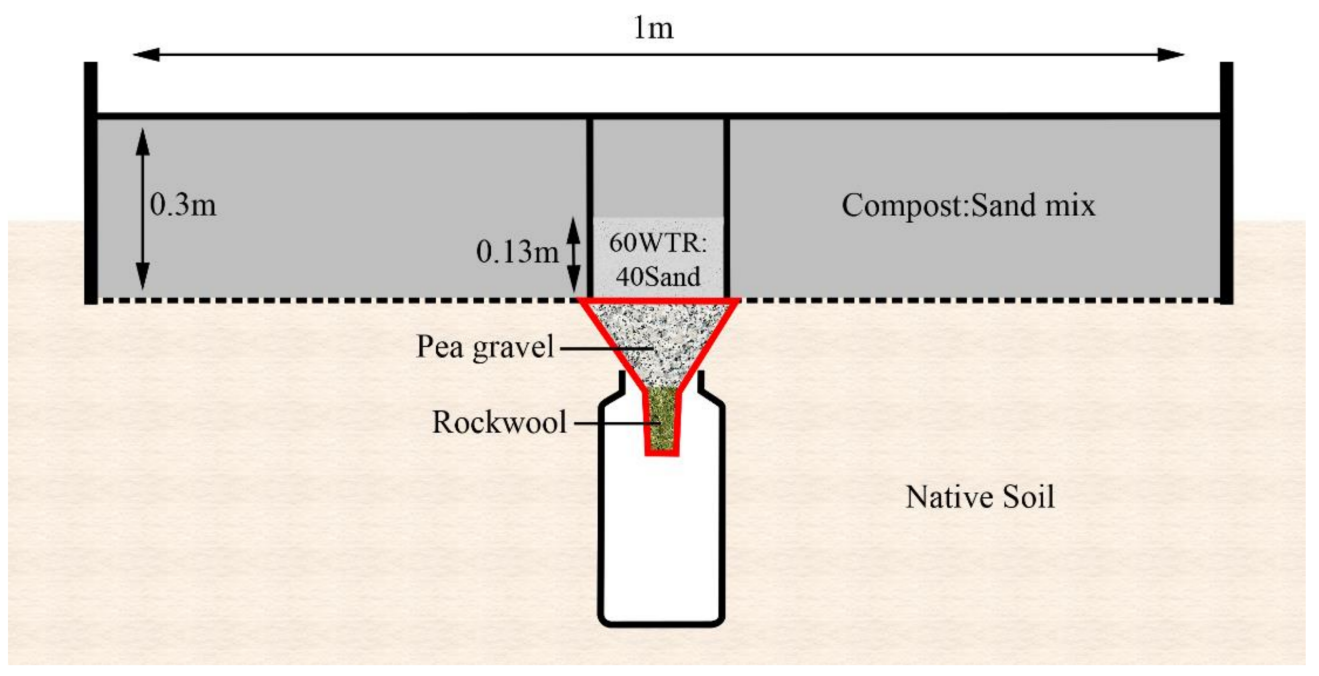

Figure 2. Cross section of bioretention soil media profile in the field and lysimeter design. Tygon tubing (not drawn) extended from the base of the Nalgene bottle through the funnel for effluent water collection. A wire mesh screen was placed directly over the funnel and holds either 60:40 spent lime (water treatment residuals (WTR)): sand mix or 100\% sand (control) and varying amounts of compost: sand mix as treatments. (Figure not drawn to scale).

While the entire raised-bed plot contained the compost-sand mixture assigned to that treatment, the spent lime treatment was only applied to a $314 \mathrm{~cm}^{2}$ area directly above the lysimeter. A wire mesh screen (opening size $2 \mathrm{~mm}$ ) separated the experimental substrate core from surrounding substrate matrix. For plots with spent lime, the mesh screen was filled with 60:40 spent lime: sand mix up to height of $13 \mathrm{~cm}$. The wire mesh helped to keep the "treatment" media (i.e., the spent lime: sand mix or the sand mix in case of control) in place directly over the lysimeter collecting the leachate water and allowed water passage from all sides. The rest of the upper screen $(17.48 \mathrm{~cm})$ and sides of the mesh was filled with the compost: sand treatment mix that was assigned to the plot. The area outside the screen was also layered with the respective compost: sand mix up to the height of the screen (Figure 2). However, over time the soil surface sunk below the mesh due to compaction of soil surface from rainfall and watering. A freeboard space of approximately 10 to $15 \mathrm{~cm}$ existed from soil surface to top of the raised bed.

Each plot was planted with two native herbaceous species recommended by University of Minnesota extension raingarden plant guide [44] on either side of the mesh (Figure 1B). The two species were Agastache foeniculum (fragrant hyssop) and Echinacae angustifolia (purple coneflower). Plants were obtained from Gertens (Inner Grove Heights, Minnesota) in 10-cm depth plugs and transplanted on May 24, 2018. Both chosen perennials are pollinator friendly and across the two species, bloom 
throughout the growing season. Plants were located outside of the experimental substrate core and the mesh prevented roots from entering, so the effects of these plants on leachate results are likely to be negligible.

Plots received ambient rainfall throughout the experiment (56.2 cm over the 153-day study) and supplemental watering ( $31 \mathrm{~cm}$ using tap water) was provided during dry periods. Water was distributed evenly over the plot surface for a constant flow and time (typically 10 or $20 \mathrm{~s}$ ) to keep input volume constant across the plots (See Supplement Table S1 for details). Dissolved nutrient concentrations in the tap water utilized in the field can be reasonably assumed to be the same as the laboratory experiment (described in Section 2.3) where $\mathrm{PO}_{4}{ }^{3-}$ and $\mathrm{NH}_{4}{ }^{+}$were non-detectable and $\mathrm{NO}_{3}{ }^{-}$concentrations were below $0.15 \mathrm{mg} \mathrm{L}^{-1}$. Plots were maintained throughout the growing season by the hand removal of weeds.

\subsection{Water Sample Collection, Nutrient Analysis and Load Estimation}

Effluent water in each lysimeter was collected approximately weekly from May 30 to October 30, 2018 ( $n=15$ sampling events), using a 50-mL polypropylene syringe with attached 3-way stopcock. Volume was measured from the syringe as the lysimeter was emptied. A 20-mL subsample was transferred in a plastic scintillation vial for analysis of leachate $\mathrm{PO}_{4}{ }^{3-}, \mathrm{NH}_{4}{ }^{+}$and $\mathrm{NO}_{3}{ }^{-}$concentrations. Water samples were either run immediately or refrigerated if run within the next $72 \mathrm{~h} . \mathrm{PO}_{4}{ }^{3-}$ concentrations were analyzed using Hanna Instruments Phosphate Low Range Portable Photometer (HI96713). Effluent $\mathrm{NH}_{4}{ }^{+}$and $\mathrm{NO}_{3}{ }^{-}$concentrations were analyzed using YSI Professional Plus Multiparameter Meter fitted with a Pro Series 1006 nitrate ISE sensor and a Pro Series 1004 ammonium ISE sensor. $10 \mathrm{~mL}$ aliquots from water samples across all replicates and five dates $(6 / 26,7 / 10,6 / 19,7 / 17$, $7 / 31$ ) were pooled for each of the treatments and analyzed for dissolved heavy metal concentrations at the Soil Testing and Research Analytical Lab at University of Minnesota. For phosphate analyzed by Hannah phosphate meter, limits of detection were 0.00 to $2.50 \mathrm{ppm}(\mathrm{mg} / \mathrm{L})$ with precision + or $0.04 \mathrm{ppm}(\mathrm{mg} / \mathrm{L})$. For nitrogen analyzed by YSI meter, limits of detection were 0.00 to $200 \mathrm{ppm}(\mathrm{mg} / \mathrm{L})$ with resolution of 0.001 to $1 \mathrm{mg} / \mathrm{L}$.

Leachate nutrient mass was calculated for all individual sampling events $(n=32)$ by multiplying nutrient concentration of the subsample of lysimeter water by the total water volume in the lysimeter: nutrient mass $(\mathrm{mg})=$ nutrient concentration $\left(\mathrm{mg} \mathrm{L}^{-1}\right) \times$ leachate volume $(\mathrm{L})$. Average leachate nutrient mass reduction by spent lime compared to control treatment was calculated based on the following formula: (average leachate mass without spent lime- average leachate mass with spent lime) $\times 100$ /average leachate mass without spent lime. If the value is positive, the spent lime treatment is effectively retaining/removing leachate nutrient mass relative to its control counterpart; if the value is negative, it is exporting nutrients.

\subsection{Laboratory Bioretention Column Study Set-up}

In the second experiment, eleven soil columns were established in the laboratory that simulated bioretention filter media designs with various media substrates for effluent testing. The columns were made from PVC and were cylindrical in shape with dimensions $47 \mathrm{~cm}$ length $\times 10 \mathrm{~cm}$ inner diameter. The columns were filled with different mixture combinations of compost, sand, spent lime and coir (composition and ratios outlined in Table 4). Coir was purchased from the Menards hardware store in Saint Paul (chemical properties in Table 2; refer to Section 2.4 for methods). A $4 \mathrm{~cm}$ headspace was maintained in all columns, so water does not overflow from the top during rainfall simulation. Spent lime was crushed and sieved through a $2 \mathrm{~mm}$ mesh screen. Like in the field study, compost was included in the top of filter media primarily to generate leaching of nutrients to the effluent as part of the experiment design, rather than adding externally. The columns were layered from top to bottom with compost, sand and spent lime or coir respectively in different volumetric ratios outlined in Table 4. Here, each of the substrate is its own layer, except when spent lime and coir were present in the same column, they were mixed thoroughly in a single layer. The bottom of the columns was 
covered with a landscape cloth permeable to water for containing the filter media. The landscape cloth was secured tightly using a rubber coupler.

Table 4. Bioretention column with different media composition.

\begin{tabular}{|c|c|c|}
\hline Column \# & ${ }^{1}$ Filter Media Layers (Top $\rightarrow$ Bottom) & Treatment Label \\
\hline 1 & $20 \%$ manure compost $+80 \%$ sand (control) & $\mathrm{M} 20+\mathrm{S} 80$ \\
\hline 2 & $\begin{array}{l}20 \% \text { manure compost }+70 \% \text { sand }+10 \% \\
\text { spent lime }\end{array}$ & $\mathrm{M} 20+\mathrm{S} 70+\mathrm{R} 10$ \\
\hline 3 & $\begin{array}{l}20 \% \text { manure compost }+70 \% \text { sand }+10 \% \\
\text { coir }\end{array}$ & $\mathrm{M} 20+\mathrm{S} 70+\mathrm{C} 10$ \\
\hline 4 & $\begin{array}{l}20 \% \text { manure compost }+70 \% \text { sand }+5 \% \\
\text { spent lime: } 5 \% \text { coir }\end{array}$ & M20+S70+R5:C5 \\
\hline 5 & $\begin{array}{l}40 \% \text { manure compost }+60 \% \text { sand } \\
\text { (control) }\end{array}$ & $\mathrm{M} 40+\mathrm{S} 60$ \\
\hline 6 & $\begin{array}{l}40 \% \text { manure compost }+50 \% \text { sand }+10 \% \\
\text { spent lime }\end{array}$ & $\mathrm{M} 40+\mathrm{S} 50+\mathrm{R} 10$ \\
\hline 7 & $\begin{array}{l}40 \% \text { manure compost }+50 \% \text { sand }+10 \% \\
\text { coir }\end{array}$ & $\mathrm{M} 40+\mathrm{S} 50+\mathrm{C} 10$ \\
\hline 8 & $\begin{array}{l}40 \% \text { manure compost }+50 \% \text { sand }+5 \% \\
\text { spent lime: } 5 \% \text { coir }\end{array}$ & $\mathrm{M} 40+\mathrm{S} 50+\mathrm{R} 5: \mathrm{C} 5$ \\
\hline 9 & $\begin{array}{l}40 \% \text { manure compost }+30 \% \text { sand }+30 \% \\
\text { spent lime }\end{array}$ & $\mathrm{M} 40+\mathrm{S} 30+\mathrm{R} 30$ \\
\hline 10 & $\begin{array}{l}40 \% \text { manure compost }+30 \% \text { sand }+30 \% \\
\text { coir }\end{array}$ & $\mathrm{M} 40+\mathrm{S} 30+\mathrm{C} 30$ \\
\hline 11 & $\begin{array}{l}40 \% \text { manure compost }+30 \% \text { sand }+15 \% \\
\text { spent lime: } 15 \% \text { coir }\end{array}$ & $\mathrm{M} 40+\mathrm{S} 30+\mathrm{R} 15: \mathrm{C} 15$ \\
\hline
\end{tabular}

${ }^{1}$ Each substrate is its own layer except when both WTR and coir is present, in which case they are mixed in a single layer. $\mathrm{M}=$ manure compost; $\mathrm{R}=$ water treatment residuals (spent lime); $\mathrm{C}=$ coir.

Fourteen rainfall simulations (See Supplement Table S2 for details) using tap water were conducted in the span of August 29 to December 4, 2018 after which effluent was collected. A simple technique involving a portable and rechargeable hand shower was used to generate rainfall lasting for $20 \mathrm{~s}$ (water overflowed the columns beyond that length) to generate effluent. Since this is comparable to a relatively short intense rainfall event, this could lead to greater nutrient leaching potential from the media in comparison to rainfall events that may be less intense. Columns were left to drain from the bottom for up to several hours. A subsample from the effluent was analyzed for $\mathrm{PO}_{4}{ }^{3-}, \mathrm{NH}_{4}{ }^{+}$and $\mathrm{NO}_{3}{ }^{-}$concentrations in the same manner as above. Tap water utilized in the study had no detectable levels of $\mathrm{PO}_{4}{ }^{3-}$ and $\mathrm{NH}_{4}{ }^{+}$, while $\mathrm{NO}_{3}{ }^{-}$concentrations were below $0.15 \mathrm{mg} \mathrm{L}^{-1}$.

\subsection{Substrate Chemical Analysis}

To determine total $\mathrm{P}$ and $\mathrm{K}$ for compost and coir samples, a 490-510 $\mathrm{mg}$ of air-dried and pulverized sample was weighed into a $20 \mathrm{~mL}$ high form silica crucible and dry ashed at $485^{\circ} \mathrm{C}$ for $10 \mathrm{~h}$. Once cooled to room temperature, the ash was equilibrated with $5 \mathrm{~mL}$ of $20 \%$ hydrochloric acid for $\frac{1}{2}$ hour. $5 \mathrm{~mL}$ of deionized water was added, gently swirled and allowed to settle for at least one hour. The supernatant was decanted into $15 \mathrm{~mL}$ plastic disposable tubes and concentrations analyzed on Inductively Coupled Plasma Atomic Emission Spectrometry (ICP-OES; iCap 7600 Duo ICP-OES Analyzer, Thermo Scientific ${ }^{\mathrm{TM}}$, Waltham, MA). Metal elemental composition of WTR was determined using microwave-assisted digestion procedure where $0.5 \mathrm{~g}$ of air dried sample was digested with $10 \mathrm{~mL}$ of nitric acid and extracts analyzed on ICP-OES [45,46]. Total C and N of compost and coir samples were determined by dry combustion where 250-350 mg of air-dried, pulverized sample was weighed into a capsule and combusted at $900{ }^{\circ} \mathrm{C}$ in the presence of oxygen within a quartz combustion tube followed by subsequent measurement of $\mathrm{CO}_{2}$ and $\mathrm{N}_{2}$ evolution in a $\mathrm{CN}$ analyzer (Elementar, Inc. VarioMAX C/N Analyzer, Ronkonkoma, NY) [47]. 


\subsection{Statistical Analysis}

For the field study, the mean of replicates was used as the experimental unit. The effects of spent lime and different volumes (or percent) of compost applied and their interaction on leachate nutrient concentrations were analyzed using two-way analysis of variance (ANOVA). One-way ANOVA was carried out to compare leachate nutrient concentrations across increasing volumes of compost for plots with and without spent lime respectively, followed by treatment means comparison using a post-hoc Tukey's honest significant test. A t-test was used to test for significant differences in effluent nutrient concentrations and mass at each compost level with and without WTR. All analysis was done on log-transformed data to meet assumptions of normality.

For the lab experiment, we carried a multiple linear regression model to test the effects of varying percent of compost, spent lime, coir and spent lime: coir mixture on leachate nutrient concentrations. One-way ANOVA followed by a post-hoc Tukey's honest significant test was carried out to test for significant differences among the different WTR and coir treatments. All analysis was done on square root transformed data to meet assumptions of normality in JMP Pro 14 [48]. Statistical significance is indicated by $\mathrm{p}<0.05$. All results are reported as mean with \pm 1 standard error (SEM).

\section{Results}

\subsection{Field Experimental Study}

\subsubsection{Treatment Effects on Leachate Nutrient Concentrations and Mass}

The volume of compost in the soil media significantly increased leachate $\mathrm{PO}_{4}{ }^{3-}$ concentrations $(\mathrm{p}<0.0001)$, whereas the presence of spent lime in the underlying soil media significantly reduced effluent $\mathrm{PO}_{4}{ }^{3-}$ concentrations $(\mathrm{p}<0.0001)$. The interaction between compost volume and spent lime on $\mathrm{PO}_{4}{ }^{3-}$ concentration was also significant $(\mathrm{p}<0.0001)$, such that without any spent lime, leachate $\mathrm{PO}_{4}{ }^{3-}$ increased significantly with increasing amounts of compost (Figure 3). Leachate $\mathrm{NH}_{4}{ }^{+}$concentrations significantly increased with compost volume $(\mathrm{p}=0.0007)$ and was lower with the presence of spent lime ( $\mathrm{p}=0.0106)$ but was not affected by compost volume and spent lime interaction. In contrast, leachate $\mathrm{NO}_{3}{ }^{-}$concentrations were higher with the presence of spent lime $(\mathrm{p}=0.0149)$ and did not differ among compost volumes $(\mathrm{p}=0.8585)$. However, significant interaction between spent lime and compost volume on leachate $\mathrm{NO}_{3}{ }^{-}$concentrations $(\mathrm{p}=0.0385)$ was observed (Figure 3$)$. 

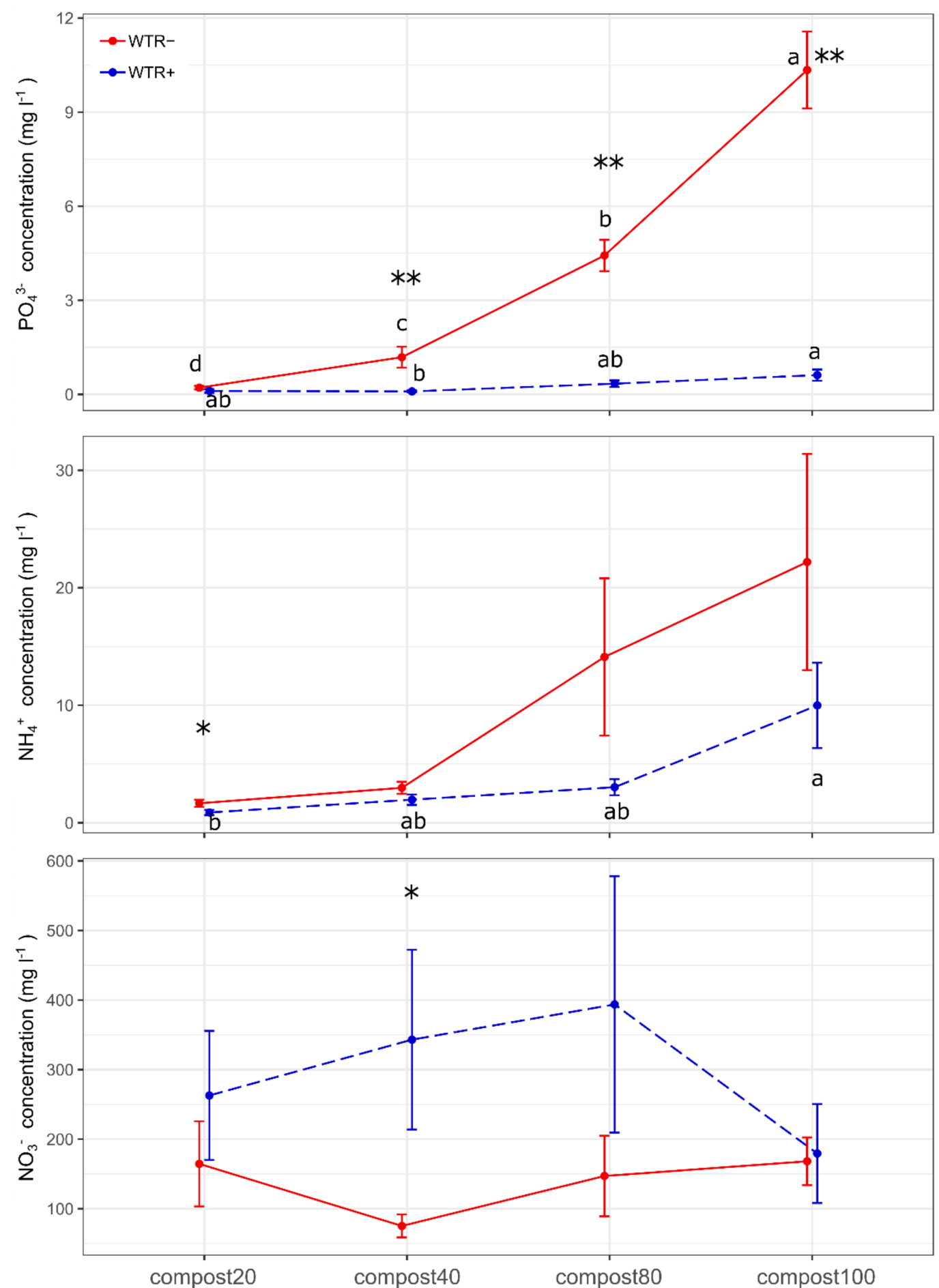

Figure 3. Mean \pm SEM leachate nutrient concentrations measured for plots with (+) and without (-) WTR (spent lime) at different levels of compost application in field-based mesocosm study. Terms with asterisks denote significant differences between plots with and without WTR at each volume of compost application. A single asterisks $\left(^{*}\right)$ is significant at the $\mathrm{p}<0.05$ level, double asterisks $\left({ }^{*}\right)$ at $\mathrm{p}<0.001$. Varying letters indicate significant differences among compost volumes within each WTR+ and WTR- plots $(\mathrm{p}<0.05)$. 
Leachate volume was variable among replicate plots (Table 5) but there were no significant differences among treatments. Spent lime treatments at the three highest $\mathrm{P}$ loading rates (compost volume $\geq 40 \%$ ) exported $93-98 \%$ less $\mathrm{P}$ compared to control treatments. There was no indication of decreased retention capacity at higher loading rates. There were no differences in $\mathrm{NH}_{4}{ }^{+}$or $\mathrm{NO}_{3}{ }^{-}$ export among treatments (Table 5).

Table 5. Mean \pm SEM effluent leachate volume $(\mathrm{mL})$ and mass $(\mathrm{mg})$ and relative difference between WTR (spent lime) treatment and control plots $(\%) . p<0.05$ indicates significant differences between WTR+ and WTR- plots and N.S. indicates not significant.

\begin{tabular}{|c|c|c|c|c|}
\hline Treatment & WTR- & WTR+ & Relative Difference (\%) & P-Value \\
\hline \multicolumn{5}{|c|}{ Volume (mL) } \\
\hline compost20 & $152 \pm \overline{38}$ & $212 \pm 80$ & -39 & N.S. \\
\hline compost 40 & $260 \pm 71$ & $148 \pm 59$ & 43 & N.S. \\
\hline compost80 & $238 \pm 68$ & $123 \pm 43$ & 48 & N.S. \\
\hline compost100 & $244 \pm 61$ & $221 \pm 71$ & 9 & N.S. \\
\hline \multicolumn{5}{|c|}{$\mathrm{PO}_{4}{ }^{3-}$ flux $(\mathrm{mg})$} \\
\hline compost20 & $0.03 \overline{ \pm 0.01}$ & $\overline{0.01 \pm 0.01}$ & 51 & N.S. \\
\hline compost 40 & $0.33 \pm 0.11$ & $0.01 \pm 0.01$ & 96 & 0.0015 \\
\hline compost80 & $1.17 \pm 0.36$ & $0.02 \pm 0.01$ & 98 & $<0.0001$ \\
\hline compost100 & $2.69 \pm 0.87$ & $0.10 \pm 0.13$ & 93 & 0.0002 \\
\hline \multicolumn{5}{|c|}{$\mathrm{NH}_{4}^{+}$flux $(\mathrm{mg})$} \\
\hline compost20 & $0.24 \pm \overline{ \pm 0.10}$ & $\overline{0.23 \pm 0.11}$ & 1 & N.S. \\
\hline compost 40 & $0.48 \pm 0.21$ & $0.20 \pm 0.10$ & 58 & N.S. \\
\hline compost80 & $2.55 \pm 1.42$ & $0.25 \pm 0.11$ & 90 & N.S. \\
\hline compost100 & $2.27 \pm 1.39$ & $0.81 \pm 0.36$ & 65 & N.S. \\
\hline \multicolumn{5}{|c|}{$\mathrm{NO}_{3}^{-}$flux $(\mathrm{mg})$} \\
\hline compost20 & $29.7 \pm 19.5$ & $76.5 \pm 67.1$ & -158 & N.S. \\
\hline compost 40 & $27.4 \pm 15.2$ & $51.9 \pm 32.8$ & -89 & N.S. \\
\hline compost80 & $31.5 \pm 17.0$ & $40.9 \pm 24.9$ & -30 & N.S. \\
\hline compost100 & $57.0 \pm 33.9$ & $74.5 \pm 67.4$ & -31 & N.S. \\
\hline
\end{tabular}

\subsubsection{Metal Concentrations with and without WTR}

As the effluent samples were pooled into one sample for chemical analysis, the effect of spent lime on effluent leachate metal concentrations could not be statistically tested at each compost level. Averaging across all compost levels, we found that spent lime did not affect heavy metal concentrations of $\mathrm{Cu}$ and $\mathrm{Mn}$, reduced $\mathrm{Al}, \mathrm{Fe}$ and $\mathrm{Zn}$ and slightly increased $\mathrm{Ni}\left(0.016\right.$ in spent lime vs. $0.013 \mathrm{mg} \mathrm{L}^{-1}$ in non-spent lime plots). Heavy metal concentrations of $\mathrm{Cd}, \mathrm{Cr}$ and $\mathrm{Pb}$ (not shown in Figure 4) in all treatments irrespective of spent lime were $<0.001 \mathrm{mg} \mathrm{L}^{-1}$. While spent lime also reduced metal cations such as B and Ca, it dramatically increased (9 times) $\mathrm{Mg}$ concentrations to the effluent (Figure 4). However, since metal concentrations changed along the compost gradient, averaging across this gradient might limit the conclusions we can draw. 

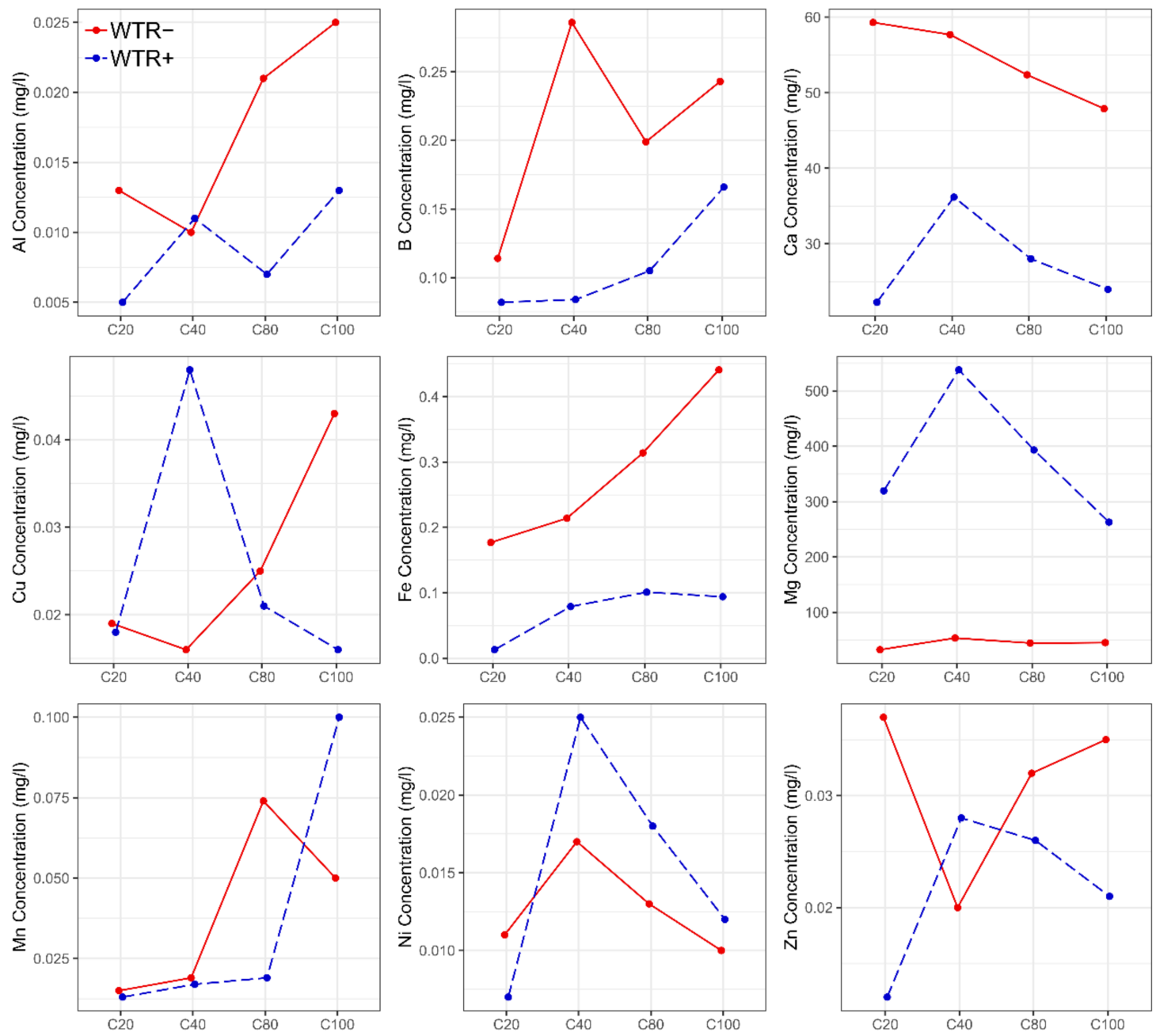

Figure 4. Leachate heavy metal concentrations measured for plots with and without WTR (spent lime) at different levels of compost application in field-based mesocosm study, where C20 $=20 \%$ compost, C40 $=40 \%$ compost, $C 80=80 \%$ compost and C100 $=100 \%$ compost.

\subsection{Laboratory Experimental Study}

\subsubsection{Effluent Nutrient Concentrations from Spent Lime and/or Coir Treatments}

Leachate $\mathrm{PO}_{4}{ }^{3-}$ concentrations were significantly increased by compost volume $(\mathrm{p}<0.0001)$, significantly decreased by spent lime and mixture of spent lime: coir $(\mathrm{p}<0.0001)$, while coir alone did not have any significant effects (model $\mathrm{R}^{2}=0.61$; See Supplement Text 1 for summary statistics). Leachate $\mathrm{PO}_{4}{ }^{3-}$ concentrations were lowest in treatments containing spent lime with varying significance compared to non-spent lime treatments (Figure 5). Of the treatments that contained spent lime, $\mathrm{PO}_{4}{ }^{3-}$ did not significantly differ among each other irrespective of compost or spent lime amounts. Leachate $\mathrm{PO}_{4}{ }^{3-}$ concentrations were highest in the column with $40 \%$ compost and $30 \%$ coir $\left(4.59 \mathrm{mg} \mathrm{L}^{-1}\right)$, while the same treatment but with $30 \%$ spent lime alternative had significantly lower P concentrations $\left(0.57 \mathrm{mg} \mathrm{L}^{-1}\right)$. Generally, treatments containing $40 \%$ compost with coir and sand have significantly higher $\mathrm{PO}_{4}{ }^{3-}$ concentrations: $\mathrm{M} 40+\mathrm{S} 30+\mathrm{C} 30, \mathrm{M} 40+\mathrm{S} 50+\mathrm{C} 10, \mathrm{M} 40+\mathrm{S} 60$, respectively. By replacing half of the coir with spent lime (i.e., M40+S50+C10 with M40+S50+R5:C5), $\mathrm{PO}_{4}{ }^{3-}$ was significantly reduced in the $40 \%$ compost treatment (Figure 5). 

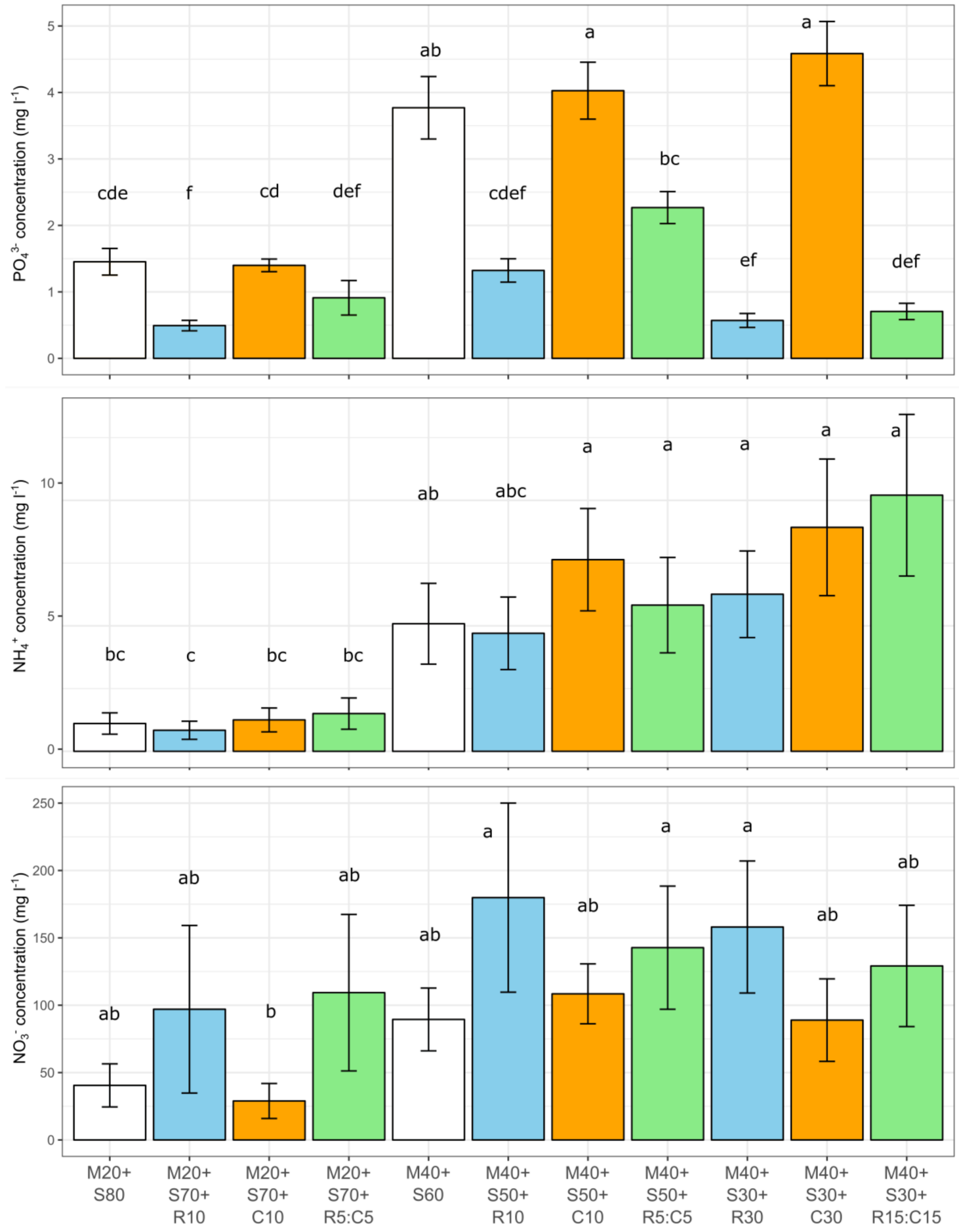

Figure 5. Mean \pm SEM leachate nutrient concentrations among different treatments containing varying volumes of compost ("M"), WTR (spent lime; “R"), coir (" $\left.\mathrm{C}^{\prime \prime}\right)$ and WTR: coir mixture in laboratory bioretention columns. Ratios of each of the substrates are indicated next to the letters. Varying letters indicate significant differences among treatments $(\mathrm{p}<0.05)$. Bars in white $=$ no WTR or coir, blue $=\mathrm{WTR}$, orange $=$ coir, green $=$ WTR: coir mix .

Compost volume significantly increased leachate $\mathrm{NH}_{4}{ }^{+}$and $\mathrm{NO}_{3}{ }^{-}$concentrations $(\mathrm{p}=0.0048$ and $\mathrm{p}<0.0001$ respectively), while various spent lime, coir and spent lime: coir mixture ratios did not significantly affect either concentrations (model $R^{2}=0.065$ and 0.33 respectively; See Supplement Text 1 for summary statistics). Of the treatments with $40 \%$ compost, no significant treatment difference 
in $\mathrm{NH}_{4}{ }^{+}$was observed. Treatment effects for $\mathrm{NO}_{3}{ }^{-}$showed less variability across treatments. The treatments with the lowest leachate $\mathrm{NO}_{3}{ }^{-}$contained either coir and/or sand in various amounts: $\mathrm{M} 20+\mathrm{S} 70+\mathrm{C} 10, \mathrm{M} 20+\mathrm{S} 80, \mathrm{M} 40+\mathrm{S} 30+\mathrm{C} 30$ and M40+S60 respectively (Figure 5).

\section{Discussion}

Both WTR (such as spent lime) and coir are waste substrates and may have the potential to be re-used on land in a sustainable manner for various purposes. Conventionally, WTR is disposed in landfills, while coir is dumped or incinerated. Over the last several decades however, new ways for their re-use have been developed, including using WTR as soil amendments to retain P in land [49-53] or the use of coir for moisture retention [22] and as plant growth media [27] but more studies with GSI applications are needed to validate water quality performance and trade-offs.

Our results show spent lime to be an effective substrate amendment to BSM for removing dissolved P from leachate, thereby increasing the effluent quality for this pollutant. While leachate $\mathrm{P}$ concentration increased significantly with increasing compost levels in the absence of spent lime, leachate $\mathrm{P}$ concentrations remained relatively uniformly low across this gradient when spent lime was added to substrate (Figure 3). While we did not directly measure P retention (as the difference between inputs and outputs), the large reduction in leachate $\mathrm{P}$ concentration and mass loss between spent lime and control treatments indicates a high capacity for $\mathrm{P}$ retention even at high $\mathrm{P}$ loading rates.

The WTR utilized in the study (spent lime) is Ca-based due to a lime-softening process used to remove hardness from the water. Most other WTR studies with respect to P- sorption have pre-dominantly studied Al or Fe-WTR [26,49,50,54], while the use of Ca-WTR in P-retention has not been as widely studied [28]. The mechanism by which Ca-WTR reduces leachate $\mathrm{PO}_{4}{ }^{3-}$ is via precipitation converting soluble $\mathrm{P}$ into insoluble $\mathrm{Ca}-\mathrm{P}$ compounds, which can be subsequently filtered out of the percolating water [55,56]. Ca-P, by immobilizing the leachate $\mathrm{PO}_{4}{ }^{3-}$, reduces the downward movement of $\mathrm{PO}_{4}{ }^{3-}$ through the BSM, which was observed in the WTR plots.

A laboratory study conducted by Elliot et al. (2002) [28] compared the ability of Ca-WTR, Al-WTR and Fe-WTR in reducing solubility and leaching from sandy soil amended with biosolids and triple superphosphate. The ability to reduce soluble P was highest for Al-WTR, while Ca-WTR and Fe-WTR were comparable to each other. Unlike Fe-P that is sensitive to redox and re-releases the adsorbed-P under anoxic conditions, Al-P and Ca-P are unaffected by changes in redox conditions and do not re-release the bound P [57]. Being unaffected by redox conditions is beneficial for application in bioretention and other GSI systems, as these systems can often be subjected to flooding during intense storms. On the other hand, calcium phosphate precipitates are weakly bonded and can become susceptible to dissolution at lower $\mathrm{pH}$, particularly below 6 [58,59], re-mobilizing $\mathrm{P}$ back into solution. Re-mobilization of $\mathrm{P}$ may not be likely in bioretention systems because $\mathrm{pH}$ of most bioretention soils tend to be somewhere around neutral ( $\mathrm{pH} 6.7-7.8[9,60,61])$, however, care must be taken to avoid $\mathrm{pH}$ to be acidic. A study by Kirkkala et al. (2002) [62] evaluated the performance of lime-sand filters containing spent lime or burnt lime on the edge of buffer zones to remove nutrients from agricultural runoff and observed a significant reduction of total and dissolved $\mathrm{P}$ in the effluent, whereas nitrogen compounds were variable over six years of monitoring.

While WTR has strong affinity for anionic species with respect to P sorption [29], WTR is also shown to improve cation exchange capacity (CEC) in soils [16,22]. In a study by Zhao et al. (2016) [63], Al-WTR applied to soils at $2 \%, 5 \%$ and $10 \%$ enhanced soil CEC by $24 \%-64 \%$. CEC influences the soil's ability to hold onto essential nutrient cations such as $\mathrm{NH}_{4}{ }^{+}$, which can suggest why treatments with WTR may have led to reduction in leachate $\mathrm{NH}_{4}{ }^{+}$concentrations, though the reduction was only significant in the compost20 treatment (Figure 3). $\mathrm{NH}_{4}{ }^{+}$mass retention of up to $90 \%$ was observed due to WTR in the compost80 treatment. To our knowledge, no other studies exist that have evaluated Ca-WTR for $\mathrm{NH}_{4}{ }^{+}$sorption. However, there are studies that have tested other Ca-rich adsorbents for $\mathrm{NH}_{4}{ }^{+}$(and $\mathrm{PO}_{4}{ }^{3-}$ ) immobilization. Zamparas et al. (2013) [64] tested bentonite, a Ca-based clay rock with a permanent negative charge, for $\mathrm{NH}_{4}{ }^{+}$and $\mathrm{PO}_{4}{ }^{3-}$ sorption and found that it was highly 
efficient at removing both the nutrients across a wide $\mathrm{pH}$ range of 5-9. Yin and Kong (2014) [65] tested attapulgite ability for $\mathrm{NH}_{4}{ }^{+}$and $\mathrm{PO}_{4}{ }^{3-}$ sorption and reported that $\mathrm{PO}_{4}{ }^{3-}$ was removed through precipitation by $\mathrm{Ca}$ and $\mathrm{NH}_{4}{ }^{+}$was exchanged with $\mathrm{Mg}$ and $\mathrm{Na}$ in the adsorbent. Given that the WTR utilized in our study (spent lime) had substantial amounts of $\mathrm{Mg}$ and some $\mathrm{Na}$ (Table 3), this cation exchange process could have led to $\mathrm{NH}_{4}{ }^{+}$sorption in the WTR-treated plots.

On the other hand, spent lime increased $\mathrm{NO}_{3}{ }^{-}$concentrations in the leachate effluent in some compost levels by up to 5 times, exhibiting increased leachate concentrations (Figure 3, Table 5). One potential explanation is that some of the $\mathrm{NH}_{4}{ }^{+}$captured in the spent lime layer underwent nitrification. Nitrification could explain the difference between treatments with and without spent lime if the presence of spent lime also causes conditions in which nitrification is promoted, resulting in more conversion of $\mathrm{NH}_{4}{ }^{+}$to $\mathrm{NO}_{3}{ }^{-}$, which warrants further investigation. Unlike $\mathrm{NH}_{4}{ }^{+}$and $\mathrm{PO}_{4}{ }^{3-}$ removal, which are more reliant on sorption and precipitation mechanisms, $\mathrm{NO}_{3}{ }^{-}$removal is dependent upon microbial denitrification and retention times of the system [66-68]. $\mathrm{NO}_{3}{ }^{-}$removal can be enhanced by certain hydrologic design modifications by creating an internal saturated zone or increasing flow retention time and media substrate modifications other than WTR alone (e.g., addition of reliable carbon source such as woodchips) to promote denitrification. Zoski et al. (2013) [68] showed significant dissolved and total $\mathrm{P}$ removal efficiencies and reductions in $\mathrm{NO}_{3}{ }^{-}$removal efficiencies from laboratory-scale bioreactors containing WTR and wood shavings under controlled flow rates. Even higher $\mathrm{NO}_{3}{ }^{-}$removals were observed from bioreactors containing wood shavings alone. In contrast, Gottschall et al. (2016) [67] showed greater removal of $\mathrm{NO}_{3}{ }^{-}$and $\mathrm{PO}_{4}{ }^{3-}$ in WTR-amended woodchip bioreactors than woodchip-only bioreactors, where bioreactors were designed to have flow retention times of $>4 \mathrm{~h}$.

Spent lime was not a source of heavy metal pollution to the effluent (except for $\mathrm{Ni}$ which slightly increased with WTR by $0.003 \mathrm{mg} \mathrm{L}^{-1}$ ). Dissolved heavy metal concentrations of $\mathrm{Cu}, \mathrm{Cd}, \mathrm{Pb}, \mathrm{Al}, \mathrm{Fe}, \mathrm{Ni}$ and $\mathrm{Zn}$ in the leachate effluent were below the threshold of EPA drinking water standards [69-71]. WTR has been used as a heavy metal adsorbent [52]. Brown et al. (2007) [71] applied Al-WTR and composted biosolid mix to contaminated soils at a superfund site and showed reduction in $\mathrm{Pd}$ and $\mathrm{Zn}$ availability. This along with other published studies show WTR to be composed of a heterogeneous mixture of inorganic elements which may include $\mathrm{Al}, \mathrm{Fe}, \mathrm{Cu}, \mathrm{Zn}, \mathrm{P}, \mathrm{Si}, \mathrm{Ca}, \mathrm{K}, \mathrm{Na}$, as well as $\mathrm{Ni}$, $\mathrm{Mo}$, $\mathrm{Cd}, \mathrm{Cr}, \mathrm{Pb}$ and sometimes As in low or negligible amounts [51,53,54,72]. WTRs may have potential to benefit soils that are deficient in micronutrients such as $\mathrm{Cu}, \mathrm{Fe}, \mathrm{Mn}$ and $\mathrm{Zn}$ [51], which could potentially be beneficial for bioretention plants. Because we did observe much higher leachate effluent $\mathrm{Mg}$ concentrations from the WTR treatments, future studies should also monitor effluent $\mathrm{pH}$ and soil $\mathrm{pH}$ to ensure plants are not adversely affected. Analysis of plant height in September 14, 2018 showed no significant difference between WTR and no-WTR plots the first year of plant establishment. In addition, future studies should also consider monitoring the potential of clogging of the BSM by the spent lime filter media application for evaluating its long-term performance.

Unlike spent lime, coir was not an effective adsorbent for $\mathrm{PO}_{4}{ }^{3-}$. We could not find any published studies where "untreated" coir has been studied for P sorption. Namasivayam and Sangeetha (2004) [73] studied $\mathrm{ZnCl}_{2}$-activated coir pith and showed positive results for $\mathrm{P}$ adsorption, attributed to ion exchange and sorption mechanisms. Feizi and Jalali (2016) [74] studied sunflower, potato, canola and walnut shell residues as biosorbents to remove $\mathrm{P}$ from aqueous solutions and showed maximum sorption of $\mathrm{P}$ in the range of $2.8-4.3 \mathrm{mgg}^{-1}$. Most studies on coir have explored its potential use as potting media and soil-less substrate for growing plants [75-79]. Hongpakdee and Ruamrungsri (2015) [75] studied water use efficiencies of potted marigold following coir amendments and showed a reduction in $\mathrm{NO}_{3}{ }^{-}$and $\mathrm{PO}_{4}{ }^{3-}$ leaching in pots amended with coir at $75 \%$ by volume. Other benefits from coir such as increased water holding capacity and increased flowering yield were also observed. More studies are needed to examine the role of coir for nutrient retention, specifically through altering coir volumes in the study design, for example, beyond what was utilized in this study. Due to a slow decomposition and low mineralization nature of coir [30], exploring coir as BSM 
amendment to stimulate plant growth and microbial activity may also be beneficial for stormwater quality improvements. Coir may also have the potential to replace compost as the primary source of organic matter (Table 2) in bioretention and other GSI systems but further research is necessary to evaluate the pros and cons of coir utilization not only from a water quality perspective but also plant health and economic viability.

Our study was not designed to be a realistic simulation of bioretention systems in terms of the source of nutrients or the volume of water received from runoff events. Instead, this study design specifically focused on determining the effects of spent lime on leachate nutrient concentration across a range of nutrient loading rates. Future studies should test the efficacy of spent lime in field-installed bioretention systems that receive nutrient-laden runoff and quantify nutrient removal efficiencies. While our study is a first step, results from our study suggest spent lime (Ca-WTR) is effective in significantly reducing leachate P concentrations from BSM. However, since field scale bioretention implementations are subjected to varying site hydrologic and environmental conditions, how long the benefits would last will likely also depend on combination of factors such as hydraulic loading ratio, pollutant loading levels, climatic factors like rainfall duration and intensity, seasonality, vegetation, maintenance and inclusion of pre-treatment at the site.

\section{Conclusions}

Because the composition of BSM is of utmost importance to water quality performance of GSI infrastructures such as bioretention, we need to have a better understanding of what kind of soil media composition in these systems might improve nutrient retention performance. As sand (or any coarse-textured soil) by itself has poor sorption capacity, a need for modified bioretention media containing substrates with high adsorption properties must be studied to identify opportunities for future improvement of these infrastructures. Results from our study suggest spent lime (Ca-WTR) to be a promising $\mathrm{P}$ adsorptive media. Field-applied spent lime also showed good retention capacity for $\mathrm{NH}_{4}{ }^{+}$and heavy metal leaching was not a concern, which further validates its application in bioretention and other GSI systems, although there is limitation in generalizing results due to variation among different sources of WTR. On the other hand, coir was not effective in reducing leachate nutrient concentrations in our study. Compared to proprietary engineered media substrates, which can be expensive to acquire, WTR is cost-effective and can be easily acquired from local drinking water treatment plants at no cost. Use of WTR for environmental pollution mitigation is also beneficial from a waste recycling perspective and reduces burdens on landfills.

Supplementary Materials: The following are available online at http://www.mdpi.com/2073-4441/11/8/1575/s1, Table S1: Supplemental watering flows and volumes to field bioretention mesocosms, Table S2: Rainfall simulation flows and volumes to laboratory columns, Text S1: Multiple linear regression model statistics.

Author Contributions: Conceptualization, P.S. and G.E.S.; methodology, P.S.; formal analysis, P.S.; investigation, P.S., M.T.S., I.J.J., N.P., M.H., H.R.W. and J.N.A.; data curation, P.S.; writing-original draft preparation, P.S.; writing-review and editing, G.E.S. and P.S.; visualization, P.S. and N.P.; supervision, P.S.; project administration, G.E.S; funding acquisition, G.E.S. and P.S.

Funding: This research was funded by the U.S. Environmental Protection Agency, grant number SU83945601 and in part by National Science Foundation CAREER award (award number 1651361) to G.E. Small.

Acknowledgments: We thank the University of St. Thomas for administrative support and undergraduate students Spencer Eugene Wihlm, Karl J. Buttel, Erin Mahre and John Patrick H. Fischer for additional assistance in the lab and field.

Conflicts of Interest: The authors declare no conflict of interest. The funders had no role in the design of the study; in the collection, analyses or interpretation of data; in the writing of the manuscript or in the decision to publish the results. 


\section{References}

1. Liao, K.-H.; Deng, S.; Tan, P.Y. Blue-Green Infrastructure: New Frontier for Sustainable Urban Stormwater Management. In Greening Cities: Forms and Functions; Tan, P.Y., Jim, C.Y., Eds.; Advances in 21st Century Human Settlements; Springer: Singapore, 2017; pp. 203-226.

2. Cook, E.A. Green site design: Strategies for storm water management. J. Green Build. 2007, 2, 46-56. [CrossRef]

3. Bratieres, K.; Fletcher, T.D.; Deletic, A.; Zinger, Y. Nutrient and sediment removal by stormwater biofilters: A large-scale design optimisation study. Water Res. 2008, 42, 3930-3940. [CrossRef] [PubMed]

4. Amanda, C.; Stephanie, H.; Carol, A. Influence of Critical Bioretention Design Factors and Projected Increases in Precipitation due to Climate Change on Roadside Bioretention Performance. J. Environ. Eng. 2018, 144, 04018082.

5. Dietz, M.E.; Clausen, J.C. A field evaluation of rain garden flow and pollutant treatment. Water Air Soil Pollut. 2005, 167, 123-138. [CrossRef]

6. Hsieh, C.H.; Davis, A.P. Evaluation and Optimization of Bioretention Media for Treatment of Urban Storm Water Runoff. J. Environ. Eng. 2005, 131, 1521-1531. [CrossRef]

7. Hunt, W.F.; Jarrett, A.R.; Smith, J.T.; Sharkey, L.J. Evaluating Bioretention Hydrology and Nutrient Removal at Three Field Sites in North Carolina. J. Irrig. Drain. Eng. 2006, 132, 600-608. [CrossRef]

8. Passeport, E.; Hunt, W.F.; Line, D.E.; Smith, R.A.; Brown, R.A. Field study of the ability of two grassed bioretention cells to reduce storm-water runoff pollution. J. Irrig. Drain. Eng. 2009, 135, 505-510. [CrossRef]

9. Shrestha, P.; Hurley, S.E.; Wemple, B.C. Effects of different soil media, vegetation and hydrologic treatments on nutrient and sediment removal in roadside bioretention systems. Ecol. Eng. 2018, 112, 116-131. [CrossRef]

10. Plant and Soil Sciences eLibrary [Internet]. Available online: http://passel.unl.edu/pages/informationmodule. php?idinformationmodule=1130447039\&topicorder $=3 \&$ maxto $=10$ (accessed on 18 July 2019).

11. Erickson Andrew, J.; Gulliver John, S.; Weiss Peter, T. Enhanced Sand Filtration for Storm Water Phosphorus Removal. J. Environ. Eng. 2007, 133, 485-497. [CrossRef]

12. Belchinskaya, L.; Novikova, L.; Khokhlov, V.; Ly Tkhi, J. Contribution of Ion-Exchange and Non-Ion-Exchange Reactions to Sorption of Ammonium Ions by Natural and Activated Aluminosilicate Sorbent [Internet]. J. Appl. Chem. 2013, pp. 1-9. Available online: https://www.hindawi.com/journals/jac/2013/789410/abs/ (accessed on 28 Febuary 2019).

13. Reddy, K.R.; DeLaune, R.D.; DeLaune, R.D. Biogeochemistry of Wetlands: Science and Applications; CRC Press: Boca Raton, FL, USA, 2008.

14. Bryant, R.B.; Buda, A.R.; Kleinman, P.J.; Church, C.D.; Saporito, L.S.; Folmar, G.J.; Bose, S.; Allen, A.L. Using Flue Gas Desulfurization Gypsum to Remove Dissolved Phosphorus from Agricultural Drainage Waters. J. Environ. Qual. 2012, 41, 664-671. [CrossRef]

15. Drizo, A.; Frost, C.A.; Grace, J.; Smith, K.A. Physico-chemical screening of phosphate-removing substrates for use in constructed wetland systems. Water Res. 1999, 33, 3595-3602. [CrossRef]

16. Köse, T.E.; Kıvanç, B. Adsorption of phosphate from aqueous solutions using calcined waste eggshell. Chem. Eng. J. 2011, 178, 34-39. [CrossRef]

17. Leader, J.W.; Dunne, E.J.; Reddy, K.R. Phosphorus Sorbing Materials: Sorption Dynamics and Physicochemical Characteristics. J. Environ. Qual. 2008, 37, 174-181. [CrossRef] [PubMed]

18. Vohla, C.; Kõiv, M.; Bavor, H.J.; Chazarenc, F.; Mander, Ü. Filter materials for phosphorus removal from wastewater in treatment wetlands-A review. Ecol. Eng. 2011, 37, 70-89. [CrossRef]

19. Wang, Z.; Dong, J.; Liu, L.; Zhu, G.; Liu, C. Screening of phosphate-removing substrates for use in constructed wetlands treating swine wastewater. Ecol. Eng. 2013, 54, 57-65. [CrossRef]

20. Lee, L.Y.; Wang, B.; Guo, H.; Hu, J.Y.; Ong, S.L. Aluminum-Based Water Treatment Residue Reuse for Phosphorus Removal. Water 2015, 7, 1480-1496. [CrossRef]

21. Liu, J.; Davis, A.P. Phosphorus speciation and treatment using enhanced phosphorus removal bioretention. Environ. Sci. Technol. 2014, 48, 607-614. [CrossRef] [PubMed]

22. Lucas William, C.; Greenway, M. Phosphorus Retention by Bioretention Mesocosms Using Media Formulated for Phosphorus Sorption: Response to Accelerated Loads. J. Irrig. Drain. Eng. 2011, 137, 144-153. [CrossRef]

23. O'Neill, S.W.; Davis, A.P. Water treatment residual as a bioretention amendment for phosphorus. II: Long-term column studies. J. Environ. Eng. 2011, 138, 328-336. [CrossRef] 
24. Palmer, E.T.; Poor, C.J.; Hinman, C.; Stark, J.D. Nitrate and Phosphate Removal through Enhanced Bioretention Media: Mesocosm Study [Internet]. Water Environ. Res. 2013, 85, 823-832.

25. Zhao, Y.; Liu, R.; Awe, O.W.; Yang, Y.; Shen, C. Acceptability of land application of alum-based water treatment residuals-An explicit and comprehensive review. Chem. Eng. J. 2018, 353, 717-726. [CrossRef]

26. Dayton, E.A.; Basta, N.T.; Jakober, C.A.; Hattey, J.A. Using treatment residuals to reduce phosphorus in agricultural runoff. J. Am. Water Works Assoc. 2003, 95, 151-158. [CrossRef]

27. Abad, M.; Noguera, P.; Puchades, R.; Maquieira, A.; Noguera, V. Physico-chemical and chemical properties of some coconut coir dusts for use as a peat substitute for containerised ornamental plants. Bioresour. Technol. 2002, 82, 241-245. [CrossRef]

28. Elliott, H.A.; O'Connor, G.A.; Lu, P.; Brinton, S. Influence of water treatment residuals on phosphorus solubility and leaching. J. Environ. Qual. 2002, 31, 1362-1369. [CrossRef] [PubMed]

29. Ippolito, J.A.; Barbarick, K.A.; Heil, D.M.; Chandler, J.P.; Redente, E.F. Phosphorus retention mechanisms of a water treatment residual. J. Environ. Qual. 2003, 32, 1857-1864. [CrossRef] [PubMed]

30. Arachchi, L.V.; Somasiri, L.L.W. Use of coir dust on the productivity of coconut on sandy soils. Cocos 1997, 12,54-71. [CrossRef]

31. Prasad, M. Physical, chemical and biological properties of coir dust. Acta Hortic. 1997, 450, 21-30. [CrossRef]

32. Handreck, K.A. Properties of coir dust and its use in the formulation of soilless potting media. Commun. Soil Sci. Plant Anal. 1993, 24, 349-363. [CrossRef]

33. Chahal, M.K.; Shi, Z.; Flury, M. Nutrient leaching and copper speciation in compost-amended bioretention systems. Sci. Total Environ. 2016, 556, 302-309. [CrossRef] [PubMed]

34. Feng, W.; Hatt, B.E.; McCarthy, D.T.; Fletcher, T.D.; Deletic, A. Biofilters for Stormwater Harvesting: Understanding the Treatment Performance of Key Metals That Pose a Risk for Water Use. Environ. Sci. Technol. 2012, 46, 5100-5108. [CrossRef]

35. Small, G.; Shrestha, P.; Kay, A. The fate of compost-derived phosphorus in urban gardens. Int. J. Des. Nat. Ecodyn. 2018, 13, 415-422. [CrossRef]

36. (2) (PDF) Stormwater Bioretention Systems: Testing the Phosphorus Saturation Index and Compost Feedstocks as Predictive Tools for System Performance [Internet]. ResearchGate. Available online: https://www.researchgate.net/publication/281942689_Stormwater_Bioretention_Systems_Testing_the_ Phosphorus_Saturation_Index_and_Compost_Feedstocks_as_Predictive_Tools_for_System_Performance (accessed on 18 July 2019).

37. Hatt, B.E.; Deletic, A.; Fletcher, T.D. Stormwater reuse: Designing biofiltration systems for reliable treatment. Water Sci. Technol. 2007, 55, 201-209. [CrossRef] [PubMed]

38. Iqbal, H.; Garcia-Perez, M.; Flury, M. Effect of biochar on leaching of organic carbon, nitrogen and phosphorus from compost in bioretention systems. Sci. Total Environ. 2015, 521-522, 37-45. [CrossRef] [PubMed]

39. Liu, K.; Elliott, J.A.; Lobb, D.A.; Flaten, D.N.; Yarotski, J. Nutrient and sediment losses in snowmelt runoff from perennial forage and annual cropland in the Canadian Prairies. J. Environ. Qual. 2014, 43, 1644-1655. [CrossRef] [PubMed]

40. The Vermont Stormwater Management Manual (VTSMM). Stormwater Treatment Standards; Vermont Agency of Natural Resources: Montpelier, VT, USA, 2016; Volume 1.

41. WA Department of Ecology. Storm Water Management Manual for Western Washington (SWMMWW); WA Department of Ecology: Olympia, WA, USA, 2019.

42. Prince George's County (PGC). Low-Impact Development Design Strategies: An Integrated Design Approach; Maryland, Department of Environmental Resources, Programs and Planning Division: Landover, MD, USA, 1999.

43. Minnesota Stormwater Manual (MSM): Compost and Stormwater Management. Minnesota Pollution Control Agency. 2017. Available online: https://stormwater.pca.state.mn.us/index.php?title=Compost_and_ stormwater_management (accessed on 18 June 2019).

44. Minnesota Pollution Control Agency (MPCA). Minnesota Stormwater Manual: Plants for Stormwater Design. 2018. Available online: https://stormwater.pca.state.mn.us/index.php/Minnesota_plant_lists (accessed on 2 January 2018).

45. Munter, R.C.; Halverson, T.L.; Anderson, R.D. Quality assurance for plant tissue analysis by ICP-AES. Commun. Soil Sci. Plant Anal. 1984, 15, 1285-1322. [CrossRef] 
46. Fassel, V.A.; Kniseley, R.N. Inductively coupled plasma. Optical emission spectroscopy. Anal Chem. 1974, 46, 1110A-1120a. [CrossRef]

47. Matejovic, I. Total nitrogen in plant material determinated by means of dry combustion: A possible alternative to determination by Kjeldahl digestion. Commun. Soil Sci. Plant Anal. 1995, 26, 2217-2229. [CrossRef]

48. SAS Institute. JMP 12.0.0 Software; SAS Institute, Inc.: Cary, NC, USA, 2015.

49. Agyin-Birikorang, S.; O'Connor, G.A. Lability of Drinking Water Treatment Residuals (WTR) Immobilized Phosphorus. J. Environ. Qual. 2007, 36, 1076-1085. [CrossRef]

50. Codling, E.E.; Chaney, R.L.; Mulchi, C.L. Biomass yield and phosphorus availability to wheat grown on high phosphorus soils amended with phosphate inactivating residues. I. Drinking water treatment residue. Commun. Soil Sci. Plant Anal. 2002, 33, 1039-1061. [CrossRef]

51. DeWolfe, J. Water Residuals to Reduce Soil Phosphorous; American Water Works Association: Denver, CO, USA, 2006; 120p.

52. Dayton, E.A.; Basta, N.T. Use of drinking water treatment residuals as a potential best management practice to reduce phosphorus risk index scores. J. Environ. Qual. 2005, 34, 2112-2117. [CrossRef]

53. Ippolito, J.A.; Barbarick, K.A.; Elliott, H.A. Drinking water treatment residuals: A review of recent uses. J. Environ. Qual. 2011, 40,1-12. [CrossRef] [PubMed]

54. Babatunde, A.O.; Zhao, Y.Q.; Burke, A.M.; Morris, M.A.; Hanrahan, J.P. Characterization of aluminium-based water treatment residual for potential phosphorus removal in engineered wetlands. Environ. Pollut. 2009, 157, 2830-2836. [CrossRef] [PubMed]

55. Tunesi, S.; Poggi, V.; Gessa, C. Phosphate adsorption and precipitation in calcareous soils: The role of calcium ions in solution and carbonate minerals. Nutr. Cycl. Agroecosyst. 1999, 53, 219-227. [CrossRef]

56. Kitano, Y.; Okumura, M.; Idogaki, M. Uptake of phosphate ions by calcium carbonate. Geochem. J. 1978, 12, 29-37. [CrossRef]

57. Lake, B.A.; Coolidge, K.M.; Norton, S.A.; Amirbahman, A. Factors contributing to the internal loading of phosphorus from anoxic sediments in six Maine, USA, lakes. Sci. Total Environ. 2007, 373, 534-541. [CrossRef] [PubMed]

58. Pinto, O.A.; Tabaković, A.; Goff, T.M.; Liu, Y.; Adair, J.H. Calcium Phosphate and Calcium Phosphosilicate Mediated Drug Delivery and Imaging. In Intracellular Delivery: Fundamentals and Applications; Prokop, A., Ed.; Springer: Dordrecht, The Netherlands, 2011; pp. 713-744.

59. Wetzel, R.G. Limnology: Lake and River Ecosystems; Gulf Professional Publishing: Houston, TX, USA, 2001; 1023p.

60. Shrestha, P.; Hurley, S.E.; Adair, E.C. Soil Media CO2 and N2O Fluxes Dynamics from Sand-Based Roadside Bioretention Systems. Water 2018, 10, 185. [CrossRef]

61. Hurley, S.; Shrestha, P.; Cording, A. Nutrient leaching from compost: Implications for bioretention and other green stormwater infrastructure. J. Sustain. Water Built Environ. 2017, 3, 04017006. [CrossRef]

62. Kirkkala, T.; Ventelä, A.-M.; Tarvainen, M. Long-term field-scale experiment on using lime filters in an agricultural catchment. J. Environ. Qual. 2012, 41, 410-419. [CrossRef]

63. Zhao, Y.; Pei, Y.; Xiang, R.; Cheng, Y. Effects of drinking water treatment residuals on the quality of different soils from southern and northern agricultural regions. Res. Environ. Sci. 2016, 29, 1497-1505.

64. Zamparas, M.; Drosos, M.; Georgiou, Y.; Deligiannakis, Y.; Zacharias, I. A novel bentonite-humic acid composite material Bephos ${ }^{\mathrm{TM}}$ for removal of phosphate and ammonium from eutrophic waters. Chem. Eng. J. 2013, 225, 43-51. [CrossRef]

65. Yin, H.; Kong, M. Simultaneous removal of ammonium and phosphate from eutrophic waters using natural calcium-rich attapulgite-based versatile adsorbent. Desalination 2014, 351, 128-137. [CrossRef]

66. Kim, H.; Seagren, E.A.; Davis, A.P. Engineered Bioretention for Removal of Nitrate from Stormwater Runoff. Water Environ. Res. 2003, 75, 355-367. [CrossRef] [PubMed]

67. Gottschall, N.; Edwards, M.; Craiovan, E.; Frey, S.K.; Sunohara, M.; Ball, B.; Zoski, E.; Topp, E.; Khan, I.; Clark, I.D.; et al. Amending woodchip bioreactors with water treatment plant residuals to treat nitrogen, phosphorus and veterinary antibiotic compounds in tile drainage. Ecol. Eng. 2016, 95, 852-864. [CrossRef]

68. Zoski, E.D.; Lapen, D.R.; Gottschall, N.; Murrell, R.S.; Schuba, B.R. Nitrogen, Phosphorus and Bacteria Removal in Laboratory-Scale Woodchip Bioreactors Amended with Drinking Water Treatment Residuals. Trans. ASABE 2013, 56, 1339-1347. 
69. United States Environmental Protection Agency. 2018 Drinking Water Standards and Advisory Tables [Internet]. US EPA, 2018. Available online: https://www.epa.gov/dwstandardsregulations/2018-drinkingwater-standards-and-advisory-tables (accessed on 18 July 2019).

70. United States Environmental Protection Agency. National Primary Drinking Water Regulation Table [Internet]. US EPA, 2016. Available online: https://www.epa.gov/ground-water-and-drinking-water/national-primarydrinking-water-regulation-table (accessed on 18 July 2019).

71. Brown, S.L.; Compton, H.; Basta, N.T. Field test of in situ soil amendments at the Tar Creek National Priorities List Superfund Site. J. Environ. Qual. 2007, 36, 1627-1634. [CrossRef]

72. Makris, K.C.; Sarkar, D.; Datta, R. Evaluating a drinking-water waste by-product as a novel sorbent for arsenic. Chemosphere 2006, 64, 730-741. [CrossRef] [PubMed]

73. Namasivayam, C.; Sangeetha, D. Equilibrium and kinetic studies of adsorption of phosphate onto $\mathrm{ZnCl}_{2}$ activated coir pith carbon. J. Colloid Interface Sci. 2004, 280, 359-365. [CrossRef]

74. Feizi, M.; Jalali, M. Sorption of aquatic phosphorus onto native and chemically-modified plant residues: Modeling the isotherm and kinetics of sorption process. Desalin. Water Treat. 2016, 57, 3085-3097. [CrossRef]

75. Hongpakdee, P.; Ruamrungsri, S. Water use efficiency, nutrient leaching and growth in potted marigolds affected by coconut coir dust amended in substrate media. Hortic. Environ. Biotechnol. 2015, 56, 27-35. [CrossRef]

76. Jeyaseeli, D.M.; Raj, S.P. Chemical characteristics of coir pith as a function of its particle size to be used as soilless medium. Ecoscan 2010, 4, 163-169.

77. Reghuvaran, A.; Ravindranath, A.D. Efficacy of biodegraded coir pith for cultivation of medicinal plants. JSIR 2010, 69, 554-559.

78. Rhie, Y.H.; Kim, J. Changes in Physical Properties of Various Coir Dust and Perlite Mixes and Their Capacitance Sensor Volumetric Water Content Calibrations. HortScience 2017, 52, 162-166. [CrossRef]

79. Tariq, U.; Rehman, S.U.; Khan, M.A.; Younis, A.; Yaseen, M.; Ahsan, M. Agricultural and municipal waste as potting media components for the growth and flowering of Dahlia hortensis 'Figaro. ' Turk. J. Bot. 2012, 36, 378-385.

(C) 2019 by the authors. Licensee MDPI, Basel, Switzerland. This article is an open access article distributed under the terms and conditions of the Creative Commons Attribution (CC BY) license (http://creativecommons.org/licenses/by/4.0/). 